\title{
MENINGKATKAN HASIL BELAJAR MATEMATIKA SISWA DENGAN \\ MENGGUNAKAN METODE DEMONSTRASI PADA SISWA KELAS IV SD NEGERI 162091 KOTA TEBING TINGGI
}

\author{
Sariannauli Purba
}

Surel: sariannulipurba@gmail.com

\begin{abstract}
This study aims to improve students' learning outcomes in Mathematics subjects through Demonstration methods. The method of this research is classroom action research (PTK). Learning by demonstration method in Mathematics lesson in Grade IV of SD Negeri 162091 Kota Tebing Tinggi has a positive impact in improving students 'interest and achievement which is marked by improvement of students' learning mastery in every cycle, that is pre cycle average 58,43, cycle I 67.81, cycle 283.12 and declared successful classically with an average of 83.12.
\end{abstract}

Keywords: Demonstration, Learning Outcomes, Mathematics

\begin{abstract}
ABSTRAK
Penelitian ini bertujuan untuk meningkatkan hasil belajar siswa mata pelajaran Matematika melalui metode Demonstrasi. Metode penelitian ini adalah penelitian tindakan kelas (PTK). Pembelajaran dengan metode demonstrasi pada pelajaran Matematika di kelas IV SD Negeri 162091 kota Tebing Tinggi memiliki dampak positif dalam meningkatkan minat dan prestasi belajar siswa yang ditandai dengan peningkatan ketuntasan belajar siswa dalam setiap siklus, yaitu yaitu pra siklus rata-rata 58,43, siklus I 67,81 , siklus 283,12 dan dinyatakan berhasil secara klasikal dengan rata-rata 83,12 .
\end{abstract}

Kata Kunci :Demonstrasi, Hasil Belajar, Matematika

PENDAHULUAN

Matematika adalah aktifitas manusia dan matematika harus dihubungkan secara nyata terhadap konteks kehidupan sehari-hari, siswa sebagai suatu sumber yang harus dikembangkan dalam kegiatan belajar mengajar. Matematika dapat menumbuhkan kemampuan siswa untuk berpikir kritis.

$$
\text { Tujuan pembelajaran }
$$
matematika adalah melatih melatih cara berpikir dalam menarik kesimpulan. Rendahnya hasil belajar disebabkan siswa menganggap matematika adalah pelajaran yang sulit. Siswa selalu mengharapkan materi yang diberikan oleh guru, dan jarang ada yang mengulang pelajaran matematika di rumah. Pada saat kegiatan belajar mengajar berlangsung keaktifan siswa dalam menjawab pertanyaan-pertanyaan yang diajukan guru sangat rendah,

Guru SDN 162091 Kota Tebing Tinggi 
hanya sebagian siswa yang aktif. Dan ketika guru menuntut siswa yang mampu bertanya tentang materi yang dipelajari, tidak ada satupun siswa yang mampu bertanya. Sama halnya ketika guru bertanya kepada siswa, apakah materi yang disampaikan guru tersebut dapat dimengerti, hanya sebagian kecil saja siswa yang menjawab. Hal ini disebabkan karena kurangnya minat siswa pada pelajaran matematika.

Sehubungan dengan itu untuk mengatasi masalah ini peranan guru sangatlah penting dan hendaknya guru mampu memberi inovasi dan metode pembelajaran yang digunakan selama ini. Pembelajaran yang digunkan hendaknya inovatif, sesuai dengan materi pelajaran yang disampaikan dan mampu diterima oleh siswa.

Metode demonstrasi adalah metode yang menggunakan suatu alat yang dapat diserap oleh mata dan telinga dengan tujuan membantu guru agar proses belajar mengajar siswa lebih efektif dan efisien (Sudjana, 2002:59). Alat peraga dalam mengajar memegang peranan penting sebagai alat bantu untuk menciptakan proses belajar mengajar yang efektif. Proses belajar mengajar ditandai dengan adanya beberapa unsur antara lain tujuan, bahan, metode, dan alat serta evaluasi.

Berdasarkan permasalahan latar belakang diatas, maka peneliti dalam melakukan penelitian ini memberi judul : Upaya meningkatkan hasil belajar Matematika siswa dengan menggunakan metode Demonstrasi pada siswa kelas IV SD Negeri 162091 Kota Tebing Tinggi Tahun pelajaran 2015/2016.

Identifikasi masalah dalam penelitian ini adalah:

a. Menyajikan materi pembelajaran guru masih menggunakan metode monoton sehingga siswa merasa bosan.

b. Hasil belajar siswa masih rendah karena tidak dapat menerima dan memahami pelajaran yang disampaikan guru dengan baik.

Sesuai dengan judul di atas peneliti mengadakan penelitian yang menitik beratkan pada masalah. "Apakah metode pembelajaran demonstarsi mampu membantu meningkatkan hasil belajar siswa kelas IV pada mata pelajaran Matematika di SD Negeri 162091 Kota Tebing Tinggi tahun pelajaran 2015/2016?".

Tujuan penelitian tindakan kelas (PTK) pada kelas IV SD Negeri 162091 mata pelajaran Matematika melalui metode pembelajaran demonstrasi adalah sebagai berikut:

1. Mengetahui bagaimana metode demonstrasi dapat meningkatkan pemahaman siswa kelas IV SD Negeri 162091 Kota Tebing Tinggi.

2. Mengetahui hasil belajar siswa menggunakan pembelajaran metode demonstrasi di kelas IV 
SD Negeri 162091 Kota Tebing Tinggi.

\section{METODE PENELITIAN}

Penelitian dilaksanakan di SD Negeri 162091 Kecamatan Padang Hulu Kota Tebing Tinggi tahun Pelajaran 2015/2016.

Subjek penelitian adalah siswa kelas IV SD Negeri 162091 Kota Tebing Tinggi Tahun Pelajaran 2015/2016 dengan jumlah siswa sebanyak 32 siswa 16 laki-laki dan 16 perempuan.

Waktu Penelitian Tindakan Kelas yaitu tepat pada bulan September sampai dengan November 2014. Adapun rencana tindakan penelitian ini adalah siklus I pada tanggal 20 Februari 2015 dan siklus II pada tanggal 02 Maret 2015.

Penelitian ini merupakan penelitian tindakan kelas (PTK), dilaksanakan melalui proses pengkajian daur ulang (siklus). Menurut Kemmis dan Taggart (1988) dalam Arikunto (2013:137) bahwa penelitian tindakan kelas terdiri atas rangkaian empat kegiatan yang dilakukan dalam siklus berulang. Empat kegiatan utama yang ada pada setiap siklus, yaitu : (a) perencanaan, (b) tindakan, (c) pengamatan, (d) refleksi, yang dapat digambarkan sebagai berikut:

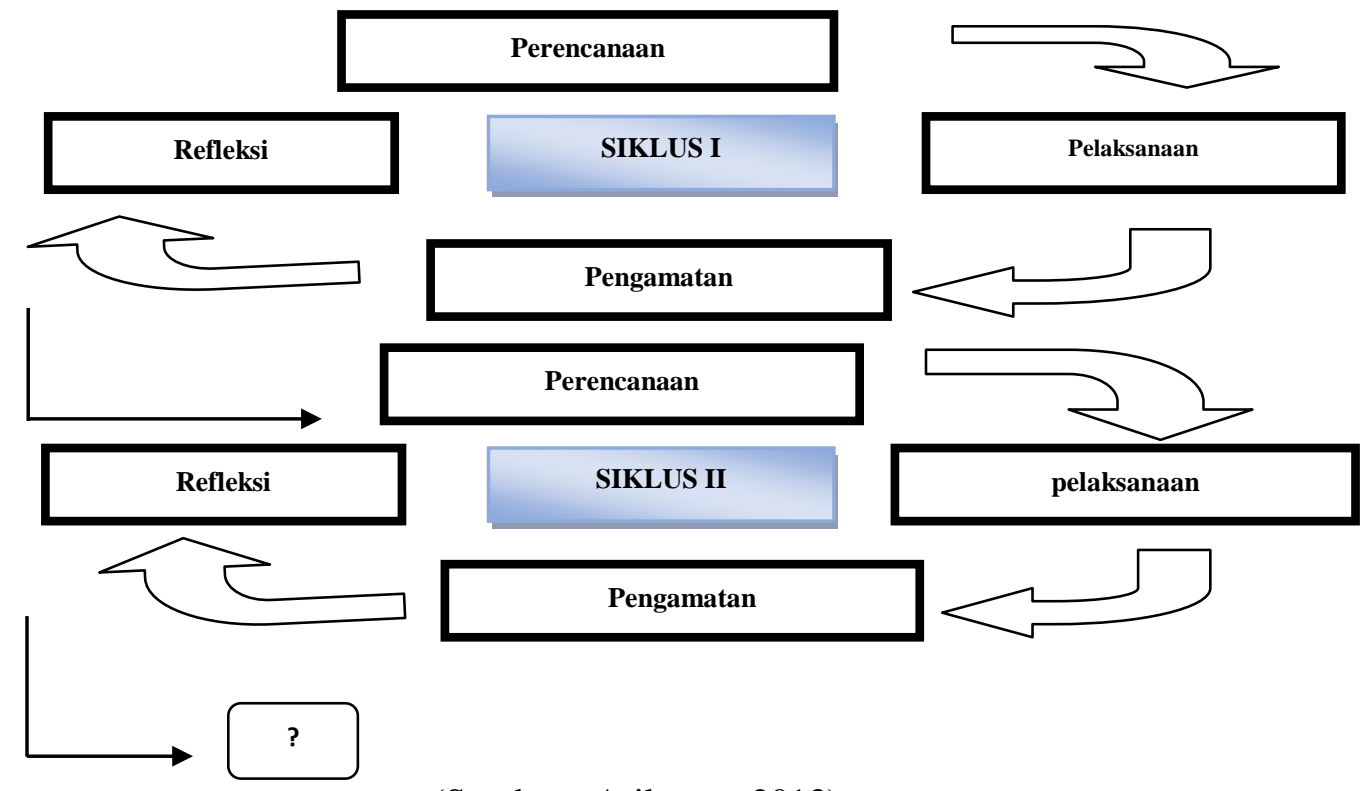

(Sumber : Arikunto, 2013)

Penelitian ini dilaksanakan dengan dua siklus.

Siklus 1

a. Perencanaan

Tahapan ini berupa menyusun rancangan tindakan yang menjelaskan tentang apa, mengapa, kapan, di mana, oleh siapa, dan bagaimana tindakan tersebut akan dilakukan. Pada tahap ini peneliti melakukana beberapa aktivitas yaitu : 
- Merumuskan tujuan yang jelas serta membuat RPP tentang materi sesuai dengan kompetensi dasar pada siklus I yaitu Memahami sifat bangun ruang sederhana dan hubungan bangun datar

- Menetapkan garis-garis besar langkah-langkah demonstrasi yang akan dilaksanakan

- Mempersiapkan lembar observasi atau lembar pengamatan aktivitas siswa selama proses belajar mengajar berlangsung.

b. Pelaksanaan

- Melaksanakan rencana pembelajaran yang telah dirancang sebelumnya.

- Menjelaskan kepada siswa tentang materi menentukan sifatsifat bangun ruang datang yaitu balok dan kubus.

- Pada saat menjelaskan pembelajaran materi, maka dijelaskan juga metode pembelajaran demonstrasi.

- Memperhatikan keadaan peserta didik, apakah semuanya mengikuti demonstrasi dengan baik.

- Memberikan kesempatan kepada siswa untuk aktif memikirkan lebih lanjut tentang apa yang dilihat dan didengarnya dalam bentuk mengajukan pertanyaan.

- Menghindari ketegangan, oleh karena itu guru hendaknya selalu menciptakan suasana yang harmonis.
- Memberikan latihan-latihan kepada siswa.

c. Observasi

- Melihat situasi kegiatan hasil pembelajaran.

- Melihat keaktifan siswa dalam pembelajaran

- Mencatat siswa yang aktif dan tidak aktif selama proses belajar berlangsung.

\section{d. Refleksi}

Mengumpulkan data dan menganalisis data yang diperoleh selama observasi sebagai pertimbangan pada siklus berikutnya.

\section{Siklus II}

Pada siklus kedua diadakan perencanaan seperti pada siklus satu yaitu tahap perencanaan, tindakan, observasi dan refleksi dalam suatu konsep yang saling terkait. Hanya saja pada siklus kedua ini ada perubahan yang menuju kearah yang lebih baik jika dibandingkan dengan siklus satu. Pada siklus II tahap yang digunakan antara lain :

a) Perencanaan

- Mengidentifikasi masalah berdasarkan refleksi pada siklus sebelumnya.

- Membuat rencana pembelajaran dengan menggunakan metode demonstrasi.

- Mempersiapkan lembar observasi atau lembar pengamatan aktivitas 
- siswa selama proses belajar mengajar berlangsung.

- Membuat tes yang akan diajukan kepada siswa untuk melihat kesu litan yang di alami siswa dalam menyelesaikan soal.

a) Pelaksanaan

- Membahas penyelesaian tes yang diberikan pada siklus I yang dianggap sulit oleh siswa, sehingga siswa yang kurang memahami konsep materi akan lebih paham.

- Memberikan kesempatan bertanya kepada siswa tentang hal-hal yang masih belum dipahami pada tahap tersebut.

- Guru memberikan metode demonstrasi dengan menggunakan alat bantuberupa alat peraga balok dan kubus sehingga siswa lebih memahami konsep materi.

- Memotivasi siswa agar selalu aktif dalam menyelesaikan soal latihan

- Menanyakan kepada siswa tentang hal-hal yang belum dipahami.

- Guru memberikan latihan kepada siswa. Guru memantau perkembangan siswa belajar dan melihat hasil kerja mereka dalam mengerjakan latihan-latihan.

- Guru memberikan tes hasil belajar yang bertujuan untuk melihat sejauh mana tingkat pemahaman konsep siswa terhadap materi pembelajaran.

\section{b) Observasi}

Melakukan pengamatan untuk melihat keaktifan siswa dalam proses pembelajaran apakah telah terlaksana sesuai dengan program pengajaran yang dilaksanakan ketika tindakan diberikan. Serta mengobservasi kegiatan guru dalam penyampaian materi.

c) Refleksi

Mengumpulkan data dan menganalisis data yang diperoleh selama observasi sebagai pertimbangan pada siklus berikutnya.

Teknik pengumpulan data dalam penelitian ini adalah tes dan lembar observasi.

1. Tes

Dalam penelitian ini diberikan tes yang bertujuan untuk mengetahui apakah kemampuan siswa meningkat berdasarkan nilai rata-rata pada tiap siklusnya melalui metode pembelajaran demonstrasi.

\section{Observasi}

Observasi ini dilakukan untuk mengetahui keaktifan siswa di kelas selama kegiatan pembelajaran berlangsung. Disamping itu tujuan observasi dilakukan untuk mengetahui adanya kesesuaian antara perencanaan dengan pelaksanaan tindakan serta aktivitas siswa dan guru di dalam kelas.

Analisis dilakukan untuk
mengetahui peningkatan metode 
demonstrasi dengan langkahlangkah sebagai berikut :

a. Nilai Individu

Nilai Individu $=\frac{\text { Jumla hskoryangdiperole } h}{\text { Jumla hskormaksimal }} \times 100 \%$ Kurnasih (2013: 43)

Kriteria penilaian:

85-100 = Tingkat aktivitas Sangat Baik

75-84 = Tingkat aktivitas Baik

65-74 = Tingkat aktivitas cukup baik

$\leq 65=$ Tingkat aktivitas kurang baik

Siswa yang memperoleh nilai $\geq 65$ maka siswa tersebut sudah dikatakan mencapai KKM pembelajaran matematika.

a. Nilai Rata-rata

$$
\overline{\mathrm{x}} \quad=\frac{\sum_{f x}}{N}
$$

Keterangan:

$$
\begin{array}{ll}
\overline{\mathrm{x}} & =\text { Nilai rata-rata } \\
\sum_{f x} & =\text { Jumlah nilai } \\
\mathrm{N} & =\text { Jumlah siswa }
\end{array}
$$

b. Nilai Klasikal

$$
\mathrm{P}=\frac{f}{N} \mathrm{X} 100 \%
$$

Keterangan:

$\mathrm{P}=$ Jumlah presentasi siswa secara klasikal

$f=$ Jumlah siswa yang mengalami perubahan

$N=$ Jumlah siswa seluruhnya

Jika jumlah siswa yang menunjukkan aktif dalam melakukan indikator aktivitas belajar $\geq 80 \%$ maka penelitian ini dinyatakan berhasil.

Untuk mendapatkan data penelitian digunakan instrumen sebagai berikut :

a. Lembar rencana pelaksanaan pembelajaran.

b. Lembar observasi kelas yang digunakan untuk pengamat selama proses pembelajaran.

c. Lembar hasil tes akhir untuk mengetahui hasil belajar siswa terhadap materi yang dipelajari.

\section{HASIL DAN PEMBAHASAN}

Hasil kegiatan pratindakan yaitu berupa kemampuan kognitif, yang dilakukan dengan pemberian test diakhir pembelajaran. Dan kegitan aktivitas belajar siswa pada saat proses belajar mengajar. Sebelum dilakukan tindakan penelitian, hasil pratindakan ini bertujuan untuk mengetahui kondisi awal kemampuan siswa pada mata pelajaran matematika dengan materi bangun datar. Siswa kelas IV SD Negeri 162091 kota Tebing Tinggi. Jumlah

\begin{tabular}{|c|c|c|c|c|}
\hline Nilai & Frekwensi & $\begin{array}{c}\text { Tuntas } \\
\text { individu }\end{array}$ & $\begin{array}{l}\text { Tuntas } \\
\text { kelas \% }\end{array}$ & $\begin{array}{c}\text { Nilai } \\
\text { rata- } \\
\text { rata }\end{array}$ \\
\hline $0-54$ & 15 & - & - & \multirow{6}{*}{58,53} \\
\hline $55-64$ & 10 & - & - & \\
\hline $65-79$ & 4 & 4 & $12,5 \%$ & \\
\hline $80-89$ & 3 & 3 & $9,37 \%$ & \\
\hline $90-100$ & - & - & - & \\
\hline Jumlah & 32 & 7 & $21,87 \%$ & \\
\hline
\end{tabular}
yang mengikuti pratindakan ini berjumlah 32 siswa. Hasil pratindakan dapat dilihat pada tabel:

Table 1.1 Hasil UH Kondisi Awal 
Pada tabel di atas menunjukkan bahwa kemampuan siswa kelas IV SD Negeri 162091 kota Tebing Tinggi dalam mata pelajaran matematika terutama bangun datar masih masuk ke dalam kategori yaitu belum tuntas. Dari 32 orang siswa 15 orang yang mendapat nilai 50,00 dan 10 orang mendapat nilai 60,00 yang mendapat nilai 70,00 sebanyak 4 orang, serta yang mendapat nilai 80 hanya 3 orang yang dinyatakan tuntas sebanyak 7 orang $(21,87 \%)$ dengan nilai rata- rata 58,53 Setelah melihat hasil pratindakan (keadaan awal) siswa yang telah dipaparkan, perlu dilakukan sebuah tindakan agar dapat meningkatkan kemampuan siswa dalam mata pelajaran matematika terutama bangun datar. Tindakan yang dilakukan adalah berupa pembelajaran dengan menggunakan model demonstrasi.

Sesuai perencanaan penelitian pada BAB III, pembelajaran dilaksanakan berdasarkan rancangan pembelajaran pada siklus1 dilaksanakan $2 \times 40 \quad$ menit. Pembelajaran dilaksanakan mengunakan model demonstrasi.

Pada tindakan siklus 1 dilaksanakan dengan, menyampaikan tujuan pembelajaran kemudian membagi kelompok siswa yang terdiri dari 6 orang dan setiap kelompok di pilih sebagai ketua untuk penanggung jawab. Setiap kelompok diberi tugasnya masingmasing. Dari hasil diskusi yang dilakukan, setiap kelompok, harus dapat mempresenatasikan hasil diskusinya. Kemudian guru memberikan kesimpulan.

Data penelitian pada siklus I ini dikumpulkan dengan teknik pengamatan test hasil belajar. Serta pengamatan dilakukan untuk mengetahui aktivitas siswa pada saat proses pembelajaran berlangsung dengan menggunakan model Demonstrasi tes hasil belajar diberikan untuk mengetahui tingkat penguasaan siswa terhadap materi pelajaran. Sedangkan aktivitas belajar siswa melalui observasi yang dilakukan oleh teman sejawat.

Data yang berhasil dikumpulkan melalui pengamatan, aktivitas belajar dapat dilihat pada table berikut.

Table 1.2 Aktvitas Siswa

Siklus 1

\begin{tabular}{|l|l|c|c|c|}
\hline No & $\begin{array}{l}\text { Aspek yang } \\
\text { dinilai }\end{array}$ & $\begin{array}{c}\text { Jumlah } \\
\text { siswa }\end{array}$ & Skor & $\begin{array}{c}\text { Presentase } \\
\text { \% }\end{array}$ \\
\hline 1 & Ketekunan & 6 & 2,00 & $18,75 \%$ \\
\hline 2 & Kerja sama & 10 & 2,50 & $31,25 \%$ \\
\hline 3 & Antusias & 15 & 1,50 & $46,87 \%$ \\
\hline 4 & $\begin{array}{l}\text { Siap } \\
\text { menerima } \\
\text { pelajaran }\end{array}$ & 12 & 2,00 & $37,5 \%$ \\
\hline & Rata-rata & & 2,00 & \\
\hline
\end{tabular}

Dari data pada table 2.1 di atas dapat kita lihat pada siklus satu ketekunan baru mencapai 6 orang $(18,75 \%)$ dengan skor 2,00 masuk dalam katagori rendah, kerjasama 10 orang $(31,25 \%)$ dengan skor 2,50 katagori rendah, dan antusias 15 orang $(46,87 \%)$ dengan skor 1,50 dengan kategori sangat rendah, dan 
siap menerima pelajaran 12 orang $(37,5 \%)$ dengan skor 2,00 kategori rendah. Aktivitas siswa pada pertemuan ini masih kategori rendah atau belum sesuai dengan apa yang diharapkan. Kemampuan siswa/ kelompok dalam mengerjakan tugas, berargumen, keaktifan, kerjasama, diskusi, motivasi dan lain-lain masih dinilai kurang. Pada saat guru menjelaskan materi pelajaran tidak sedikit siswa yang ngobrol dengan teman sebangkunya dan tidak memperhatikan. Bahkan ketika guru bertanya "apa sudah jelas belum?", siswa tidak menjawab dan akhirnya ketika diberi pertanyaan siswa tidak bisa menjawab.

Beberapa aspek yang mendapat nilai kurang baik di atas merupakan suatu kelemahan yang terjadi pada siklus I dan akan dijadikan bahan kajian untuk refleksi dan revisi yang akan dilakukan pada siklus II. Selain melakukan observasi pada aktivitas siswa, dilakukan juga observasi pada kegiatan guru dalam pembelajaran matematika terpadu melalui media gambar berbasis diskusi pada proses pembelajaran. Hasil observasi berikutnya adalah observasi kegiatan guru oleh observator dapat dilihat pada tabel berikut :

Tabel 1. 3. Hasil Observasi Kegiatan Guru Siklus I

\begin{tabular}{|l|c|c|c|}
\hline \multicolumn{1}{|c|}{$\begin{array}{c}\text { ASPEK YANG } \\
\text { DIOBSERVASI }\end{array}$} & \multicolumn{2}{|c|}{ KEMUNCULAN } & \multirow{2}{*}{ KET } \\
\cline { 2 - 3 } & ADA & NILAI & \\
\hline Tujuan Perbaikan & $\sqrt{ }$ & 3 & Tinggi \\
\hline $\begin{array}{l}\text { Langkah-langkah } \\
\text { Pembelajaran }\end{array}$ & $\sqrt{ }$ & 3 & Tinggi \\
\hline Alat Peraga & $\sqrt{ }$ & 2 & Rendah \\
\hline
\end{tabular}

\begin{tabular}{|c|c|c|c|}
\hline $\begin{array}{l}\text { Siswa menyelesaikan } \\
\text { soal-soal latihan tepat } \\
\text { waktu }\end{array}$ & - & - & - \\
\hline $\begin{array}{lr}\text { Siswa } & \text { menjawab } \\
\text { pertanyaan } & \text { dengan } \\
\text { benar } & \\
\end{array}$ & & 2 & Rendah \\
\hline $\begin{array}{lr}\text { Siswa } & \text { menyelesaikan } \\
\text { tugas } & \text { latihan } \\
\text { menggunakan semua } \\
\text { langkah-langkah }\end{array}$ & & 2 & Rendah \\
\hline $\begin{array}{ll}\text { Penjelasan } & \text { guru yang } \\
\text { mudah } & \text { dimengerti } \\
\text { siswa } & \end{array}$ & & 3 & Rendah \\
\hline Melakukan evaluasi & & 3 & Tinggi \\
\hline $\begin{array}{lll}\text { Interaktif siswa dan } \\
\text { guru }\end{array}$ & & 2 & Rendah \\
\hline $\begin{array}{l}\text { Kreatif guru } \\
\text { mempergunakan media } \\
\text { pembelajaran }\end{array}$ & $\sqrt{ }$ & 2 & Rendah \\
\hline $\begin{array}{l}\text { Menggunakan } \quad \text { Multi } \\
\text { Metode }\end{array}$ & $\sqrt{ }$ & 2 & Rendah \\
\hline Rata-rata & & 2,09 & Rendah \\
\hline
\end{tabular}

Keterangan :

1,0 - 1,74 Sangat rendah

$1,75-2,49 \quad$ Rendah

2,50-3,24 Tinggi

$3,25-4,00 \quad$ Sangat tinggi

Berdasarkan tabel di atas aspek-aspek yang mendapatkan kriteria rendaholeh kolaborator adalah alat Peraga, siswa menjawab pertanyaan dengan benar, siswa menyelesaikan tugas latihan menggunakan semua langkahlangkah, interaktif siswa dan guru, kreatif guru mempergunakan media pembelajaran,dan menggunakan multi metode.

Guru terlihat belum dapat mengelola diskusi dengan baik sehingga masih banyak siswa yang ribut selama kegiatan belajar mengajar. Guru juga belum mampu membimbing dan mengawasi siswa 
dengan baik selama proses pembelajaran. Ketika guru memberikan tugas kepada siswa, guru lebih banyak menulis administrasi kegiatan pembelajaran dibandingkan mengawasi kerja setiap siswa sehingga tidak jarang banyak siswa yang main-main,sehingga siswa menyelesaikan soal-soal latihan tidak seorang pun yang melakukan tepat waktu tepat waktu

Beberapa aspek yang mendapat nilai kurang baik di atas merupakan suatu kelemahan yang terjadi pada siklus I dan akan dijadikan bahan kajian untuk refleksi dan revisi yang akan dilakukan pada siklus II.

Setelah dilakukan penilaian test hasil belajar siswa diakhir pembelajaran pada siklus 1 ditemukan adanya peningkatan hasil belajar terhadap siswa kelas IV SD Negeri 162091 adapun hasil tersebut dapat kita lihat melalui tabel berikut:

Tabel 1.4 Hasil Belajar Siswa Siklus 1

\begin{tabular}{|c|c|c|c|c|}
\hline Nilai & frekwensi & $\begin{array}{c}\text { Tuntas } \\
\text { individu }\end{array}$ & $\begin{array}{c}\text { Tuntas } \\
\text { kelas } \\
\%\end{array}$ & $\begin{array}{c}\text { Nilai } \\
\text { rata- } \\
\text { rata }\end{array}$ \\
\hline $0-50$ & 3 & - & - & \multirow{6}{*}{67,81} \\
\hline $\begin{array}{c}55- \\
64\end{array}$ & 9 & - & - & \\
\hline $\begin{array}{c}65- \\
79\end{array}$ & 15 & 15 & $\begin{array}{c}46,87 \\
\%\end{array}$ & \\
\hline $80-89$ & 4 & 4 & $12,5 \%$ & \\
\hline $\begin{array}{l}90- \\
100\end{array}$ & 1 & 1 & $3,12 \%$ & \\
\hline Jumlah & 32 & 20 & $62,5 \%$ & \\
\hline
\end{tabular}

Dari data di atas dapat kita lihat telah terjadinya peningkatan dari hasil belajar siswa pada siklus 1. Pada siklus ini dapat di uraikan siswa yang mendapat nilai kategori sangat rendah sebanyak 3 orang dengan nilai 50,00 dan nilai yang mendapat 60,00 sebanayk 9 orang dengan kategori rendah, kemudian nilai yang mendapat kategori sedang sebanyak, 15 orang dengan nilai 70,00 serta yang mendapat nilai 80 sebanyak 4 orang dengan kategori tinggi, kemudian terjadi lagi peningkatan untuk kategori sangat tinggi telah mencapai nilai 90,00 sebanyak 1 orang.

Setelah siklus I selesai dilaksanakan dan berdasarkan dari hasil test serta pengamatan observasi siswa, dapat terlihat terjadinya peningkatan untuk ketuntasan kelas pratidakan $21,87 \%$ naik menjadi $62,42 \%$ pada siklus 1 dan untuk rata - rata kelas juga terjadi peningkatan pratindakan 58,53 menjadi 62,42 pada siklus 2 setelah disimpulkan bahwa hasil penelitian belum sesuai dengan indikator keberhasilan, maka akan dilanjutkan pada siklus berikutnya. Kelemahan yang terjadi pada siklus 1 akan di perbaiki pada siklus 2 dengan melakukan tindakan tindakan. Pada saat pembelajaran siswa cenderung melakukan aktifitas lain yang lebih menarik perhatian siswa sehingga tidak terpusat penuh terhadap materi pelajaran.

Selain itu dalam diskusi kelompok, banyak siswa yang mengandalkan jawaban temannya dibandingkan menjawab sendiri. Namun demikian, pembelajaran yang 
dilaksanakan telah mampu meningkatkan hasil belajar siswa dibandingkan dengan sebelum dilakukan tindakan meskipun belum mencapai kriteria ketuntasan belajar yang diharapkan. Oleh karena itu dilanjutkan penelitian siklus kedua untuk meningkatkan hasil belajar siswa.

Pembelajaran dilaksanakan berdasarkan rancangan pembelajaran pada siklus 2 dilaksanakan 2 x 45 menit. Pembelajran dilaksanakan mengunakan model demonstrasi.

Pada tindakan siklus 2 dilaksanakan dengan menyampaikan tujuan pembelajaran kemudian membagi kelompok siswa yang terdiri dari 6 orang secara hetrogen,setiap memilih ketua kelompoknya masing-masing. dan setiap kelompok di beri tugas. Dan setiap kelompok harus siap untuk mempresentasikan hasil diskusinya. Kemudian guru dan siswa membuat kesimpulan.

Dari data penelitian pada siklus 2 sama seperti dengan siklus 1 yaitu dengan teknik pengamatan test hasil belajar. Serta pengamatan yang dilakukan untuk mengetahui aktivitas siswa pada saat proses pembelajaran berlangsung dengan menggunakan model demonstrasi tes hasil belajar diberikan untuk mengetahui tingkat penguasaan siswa terhadap materi pelajaran. Sedangkan aktivitas belajar siswa melalui observasi yang dilakukan oleh teman sejawat.
Data yang berhasil dikumpulkan melalui pengamatan, aktivitas belajar dapat dilihat pada table berikut.

\section{Table 1.5 Aktivitas Belajar Siklus II}

\begin{tabular}{|c|l|c|c|c|}
\hline No & $\begin{array}{c}\text { Aspek } \\
\text { yang } \\
\text { dinilai }\end{array}$ & $\begin{array}{c}\text { Jumlah } \\
\text { siswa }\end{array}$ & Skor & $\begin{array}{c}\text { Presentase } \\
\%\end{array}$ \\
\hline 1 & Ketekunan & 30 & 4,00 & 93,75 \\
\hline 2 & $\begin{array}{l}\text { Kerja } \\
\text { sama }\end{array}$ & 32 & 3,50 & $100 \%$ \\
\hline 3 & Antusias & 28 & 3,25 & $87 \%$ \\
\hline 4 & $\begin{array}{l}\text { Siap } \\
\text { menerima } \\
\text { pelajaran }\end{array}$ & 30 & 4,00 & $93,75 \%$ \\
\hline & Rata-rata & & 3,68 & \\
\hline
\end{tabular}

Dari tabel data di atas dapat dilihat pada siklus 2 ini telah banyak peningkatan dari pada siklus 1 . Ketekunan pada siklus 2 mencapai 30 orang $(93,75 \%)$ dengan skor 4,00 katagori sangat tinggi. Kerja sama 32 orang $(100 \%)$ skor 3,50 katagori sangat tinggi, antusias 28 skore 3,25 orang $(87 \%)$ katagori sangat tinggi, dan siap menerima pelajaran 30 orang $(93,75 \%)$ dengan sangat tinggi. Aktivitas siswa pada siklus kedua ini sudah mengalami kemajuan. Siswa sudah aktif dalam mengikuti pembelajaran. Pada siklus ini, siswa mampu menjawab pertanyaan yang diberikan oleh guru. Siswa juga sudah berani untuk bertanya kepada guru jika belum mengerti. Suasana belajar menjadi aktif dan interaktif pada siklus ini persentase aktivitas siswa sudah mencapai optimal. Selain itu guru juga sudah bisa memantau dan mengarahkan kerja siswa dalam melaksanakan diskusi. 
Selain melakukan observasi pada aktivitas siswa, dilakukan juga observasi pada kegiatan guru dalam pembelajaran matematika. Hasil observasi berikutnya adalah observasi kegiatan guru oleh observator dapat dilihat pada tabel berikut :

\section{Tabel 1.6. Hasil Observasi Kegiatan} Guru Siklus II

\begin{tabular}{|c|c|c|c|}
\hline \multirow{2}{*}{$\begin{array}{l}\text { ASPEK YANG } \\
\text { DIOBSERVASI }\end{array}$} & \multicolumn{2}{|c|}{ KEMUNCULAN } & \multirow{2}{*}{ KET } \\
\hline & ADA & NILAI & \\
\hline Tujuan Perbaikan & $\sqrt{ }$ & 4 & $\begin{array}{l}\text { Sangat } \\
\text { tinggi }\end{array}$ \\
\hline $\begin{array}{l}\text { Langkah-langkah } \\
\text { Pembelajaran }\end{array}$ & $\sqrt{ }$ & 4 & $\begin{array}{l}\text { Sangat } \\
\text { tinggi }\end{array}$ \\
\hline Alat Peraga & $\sqrt{ }$ & 3,5 & $\begin{array}{l}\text { Sangat } \\
\text { tinggi }\end{array}$ \\
\hline $\begin{array}{l}\text { Siswa } \\
\text { menyelesaikan soal- } \\
\text { soal latihan tepat } \\
\text { waktu }\end{array}$ & $\sqrt{ }$ & 3 & Tinggi \\
\hline $\begin{array}{l}\text { Siswa menjawab } \\
\text { pertanyaan dengan } \\
\text { benar }\end{array}$ & $\sqrt{ }$ & 3 & Tinggi \\
\hline $\begin{array}{l}\text { Siswa } \\
\text { menyelesaikan tugas } \\
\text { latihan } \\
\text { menggunakan } \\
\text { semua langkah- } \\
\text { langkah }\end{array}$ & $\sqrt{ }$ & 3 & Tinggi \\
\hline $\begin{array}{l}\text { Penjelasan guru } \\
\text { yang mudah } \\
\text { dimengerti siswa }\end{array}$ & $\sqrt{ }$ & 3,5 & $\begin{array}{l}\text { Sangat } \\
\text { tinggi }\end{array}$ \\
\hline Melakukan evaluasi & $\sqrt{ }$ & 3 & Tinggi \\
\hline $\begin{array}{l}\text { Interaktif siswa dan } \\
\text { guru }\end{array}$ & $\sqrt{ }$ & 3,5 & $\begin{array}{l}\text { Sangat } \\
\text { tinggi }\end{array}$ \\
\hline $\begin{array}{l}\text { Kreatif guru } \\
\text { mempergunakan } \\
\text { media pembelajaran }\end{array}$ & $\sqrt{ }$ & 3 & Tinggi \\
\hline $\begin{array}{l}\text { Menggunakan Multi } \\
\text { Metode }\end{array}$ & $\sqrt{ }$ & 3 & Tinggi \\
\hline Rata -rata & & 3,40 & $\begin{array}{l}\text { Sangat } \\
\text { tinggi }\end{array}$ \\
\hline
\end{tabular}

Berdasarkan tabel di atas aspek-aspek kegiatan guru mengalami peningkatan dibandingkan dengan siklus sebelumnya. Secara keseluruhan guru mampu menyampaikan materi pelajaran dengan baik. Guru lebih melibatkan siswa baik dalam kegiatan inti maupun pada saat refleksi dan kerangkuman pembelajaran. Siswa memahami konsep-konsep pembelajaran dengan menggunakan model Demonstrasi. Aktivitas guru dalam pembelajaran sudah sesuai dengan rencana dan sudah efektif artinya lebih difokuskan pada kegiatan inti siswa yaitu dalam kegiatan belajar kelompok melalui model pembelajaran demonstrasi. Guru lebih melibatkan siswa baik dalam kegiatan inti maupun pada saat refleksi dan kerangkuman pembelajaran. Siswa memahami konsep-konsep pembelajaran dengan melihat langsung dan memahami tentang materi yang dipelajari. Guru memberikan dorongan/motivasi kepada siswa untuk lebih giat bekerja dan memberikan sumbangsih pemikiran kepada kelompoknya.

Hasil belajar siswa pembelajaran matematika melalui tes ulangan harian dapat dilihat pada tabel berikut:

Tabel 1.7 Hasil Belajar Siswa

\begin{tabular}{|c|c|c|c|c|}
\hline Nilai & frekwensi & $\begin{array}{c}\text { Tuntas } \\
\text { individu }\end{array}$ & $\begin{array}{c}\text { Tuntas } \\
\text { kelas } \\
\%\end{array}$ & $\begin{array}{c}\text { Nilai } \\
\text { rata- } \\
\text { rata }\end{array}$ \\
\hline $0-50$ & - & - & - & \multirow{2}{*}{} \\
\cline { 1 - 4 } $55-64$ & - & - & - & \multirow{2}{*}{83,12} \\
\hline $65-79$ & 1 & 1 & $3,12 \%$ & \\
\hline $80-89$ & 20 & 20 & $62,5 \%$ & \\
\hline $90-100$ & 11 & 11 & $34,37 \%$ & \multirow{2}{*}{} \\
\cline { 1 - 3 } Jumlah & 32 & 32 & $100 \%$ & \\
\hline
\end{tabular}

Dari data pada tabel yang ada dapat di uraikan hasil belajar siswa setelah proses pembelajaran berakhir, 
pada siklus 2 dapat kita lihat hasil test yang dilaksanakan, yang mendapat nilai 70,00 sebanyak 1 orang $(3,12 \%)$ dalam katagori sedang,sebanyak 20 orang $(62,5 \%)$ mendapat nilai 80,00 masuk dalam katagori tinggi. Sedangkan 11 orang $(34,37 \%)$ mendapat nilai 90,00 dalam katagori sangat tinggi. Ketuntasan persentasi klasikal di peroleh $100 \%$ ketuntasan hasil belajar dari $100 \%$ ketuntasan klasikal, dengan nilai rara- rata 83,12. Setelah dilakukan pengamatan dengan merujuk pada tabel-tabel hasil test yang telah dipaparkan sebelumnya,dapat dilihat nilai ratarata test ketuntasan siswa klasikalnya mengalami peningkatan. Peningkatan hasil belajar siklus satu dan siklus dua tersebut juga telah mencapai ketuntasan klasikal yang diharapkan. Begitu juga halnya dengan aktivitas belajar siswa juga dan aktivitas kegiatan guru mengalami peningakatan yang cukup tinggi. Dengan demikian KBM siklus 1 dan KBM siklus 2 telah berhasil memberikan ketuntasan belajar secara klasikal.

Sebelum melakukan siklus 1 terlebih dahulu peneliti melihat hasil UH yang dilakukan, dengan demikian peneliti dapat melihat kemampuan awal siswa. Merujuk pada tabel 1 (pratindakan) tentang hasil UH anak yang tuntas sebanyak 7 orang, baru mencapai $21,7 \%$ untuk tuntas klasikal. Berdasarkan hasil data yang dikumpulkan, dapat dikemukakan dua hal pokok yang perlu diatasi yaitu menumbuhkan aktivitas belajar siswa dengan cara mengaktifkan siswa dalam kegiatan belajar mengajar, dan meningkatkan prestasi belajar siswa melalui Model Pembelajaran Demonstrasi.

Dari hasil pengamatan dapat di temukan rekapitulasi aktivitas belajar siswa setiap siklus pada table berikut:

Tabel 1.8 Rekapitulasi Aktivitas Belajar Tiap Siklus

\begin{tabular}{|l|l|c|c|}
\hline No & \multicolumn{1}{|c|}{$\begin{array}{c}\text { Aspek } \\
\text { penilaian }\end{array}$} & Siklus 1 & $\begin{array}{c}\text { Siklus } \\
\mathbf{2}\end{array}$ \\
\hline 1 & Ketekunan & $18,75 \%$ & $93,75 \%$ \\
\hline 2 & Kerja sama & $31,25 \%$ & $100 \%$ \\
\hline 3 & Antusias & $46,87 \%$ & $87 \%$ \\
\hline 4 & $\begin{array}{l}\text { Siap } \\
\text { meneriama } \\
\text { pelajaran }\end{array}$ & $37,5 \%$ & $93,75 \%$ \\
\hline
\end{tabular}

Berdasarkan hasil observasi aktivitas diprogramkanbelajar yang telah, dan dilaksanakan telah mampu mencapai tujuan yang diharapkan dalam penelitian. Pada siklus satu siswa yang tekun $(18,75 \%)$, terjadi peningkatan pada siklus dua $(93,75 \%)$ kerja sama pada siklus satu $(31,25 \%)$ menjadi peningkatan (100\%) pada siklus dua, antusias $46,87 \%$ pada siklus satu menjadi( $87 \%$ ) pada siklus dua,dan untuk siap menerima pelajaran $(37,5 \%)$ pada siklus satu peningkatan terjadi pada siklus dua $(93,75 \%)$. Dirujuk dari table pengamatan aktivitas siswa telah mencapai indikator ketuntasan. Peningkatan akitvitas belajar siswa pada siklus satu dan siklus dua yang artinya pengelolaan pembelajaran aktifitas siswa sudah dinilai dalam 
kategori sangat baik.Hasil ini sudah melebihi kriteria pencapaian ketuntasan belajar yang ditentukan pada penelitian ini.

Dari hasil pengamatan dapat di temukan rekapitulasi hasil belajar siswa setiap siklus pada tabel berikut:

Tabel 1.9 Rekapitulasi Data Awal, Siklus 1, dan Siklus II

\begin{tabular}{|c|c|c|c|}
\hline Nilai & $\begin{array}{c}\text { Data } \\
\text { awal }\end{array}$ & Siklus 1 & Siklus 2 \\
\hline 50 & 15 & 3 & - \\
\hline 60 & 10 & 9 & - \\
\hline 70 & 4 & 15 & 1 \\
\hline 80 & 3 & 4 & 20 \\
\hline 90 & - & 1 & 11 \\
\hline Rata-rata & 58,43 & 67,81 & 83,12 \\
\hline
\end{tabular}

Berdasarkan hasil penilaian siswa, dapat merujuk pada tabel 1.7 yang merupakan rekapitulasi dari data awal dan persiklus. Dari data yang ada dapat dilihat nilai katagori terendah 50,00 sebanyak 15 orang untuk data awal, setelah dilakukan perbaikan terjadi penurunan sebanyak 3 orang pada siklus, dan nilai katagori rendah 60,00 sebanyak 10 orang pada data awal, terjadi penurunan siklus satu sebanyak 9 orang, untuk nilai 70,00 dengan katagori tinggi untuk data awal sebanyak 4 orang terjadi peningkatan untuk siklus satu sebanyak 15 orang dan siklus dua terjadi penurunan sebanyak 1 orang. Nilai katagori tertinggi dengan nilai 80,00 sebanyak 3 orang pada data awal, untuk siklus 1, terjadi peningkatan sebanyak 4 orang terjadi peningkatan pada siklus dua sebanyak 20 orang, kemudian untuk nilai katagori sangat tinggi 90,00 sebanyak 1 orang untuk siklus satu terjadi peningkatan untuk siklus dua sebanyak 11 orang. Berdasarkan hasil observasi, aktivitas diskusi kelompok, dan hasil tes siklus 2 dapat di evaluasi bahwa langkah-langkah yang telah diprogramkan dan dilaksanakan mampu mencapai tujuan yang diharapkan dalam penelitian. Dengan demikian melalui model demonstrasi dapat meningkatkan minat belajar siswa yang ditandai dengan meningkatnya aktivitas dan hasil belajar siswa.

\section{SIMPULAN}

Berdasarkan temuan dan pembahasan yang dipaparkan diatas, dikemukakan beberapa kesimpulan sebagai berikut:

1. Hasil belajar siswa dalam mata pelajaran matematika dapat ditingkatkan dengan mengunakan model demonstrasi dengan memperbanyak latihan membuat, mempelajari dan menemukan astribut-astribut suatu konsep atau pengertian yang dipelajari.

2. Suasana belajar akan berubah kearah yanglebih baik jika dalam setiap proses pembelajaran diakhiri dengan test untuk mengetahui hasil belajar siswa .

3. Peningkatan frekwensi pemberian latihan menyelesaikan soal-soal ketika proses pembelajaran berlangsung dapat meningkatkan hasil belajar siswa. 
Berdasarkan kesimpulan di atas diajukan beberapa saran tindak lanjut, yaitu:

1. Sebagai seorang guru, peneliti akan berupaya meneruskan pemberian umpan balik dan penghargaan tehadap pekerjaan dan tugas-tugas yang telah di selesaikan oleh siswa.

2. Pemberian penghargaan yang dapat diberikan dapat berbentuk Penghargaan varbal berupa pujian dan kata-kata positif juga nonVerbal berupa sikap positif dan kedekatan guru dengan siswa.

3. Penelitian akan menginformasikan keberhasilan ini kepada teman-teman sejawat untuk memaksimalkan pemberian umpan balik dan penghargaan kepada siswa.

\section{DAFTAR RUJUKAN}

Arikunto, Suharsimi. 2002. Prosedur Penelitian Suatu

Pendekatan Praktek. Jakarta: Rineksa Cipta.

Ali, Muhammad. 1996. Guru Dalam Proses Belajar Mengajar. Bandung: Sinar Baru Algesindon.

Hadi, Sutrisno. 1982. Metodologi Research, Jilid 1. Yogyakarta: YP. Fak. Psikologi UGM.

Lee, W.R. 1985. Language Teaching Games and Contests.
London: Oxfortd University Press.

Melvin, L. Siberman. 2004. Aktif Learning, 101 Cara Belajar Siswa Aktif. Bandung: Nusamedia dan Nuansa.

Sudjana, Nana. 1989. Dasar-dasar Proses Belajar Mengajar. Bandung: Sinar Baru.

Sukmadinata, Nana Syaodih. 2004. Metode Penelitian Pendidikan. Bandung: PT. Remaja Rosdakarya. 